\title{
ENVIRONMENTAL IMPACT OF THE BRAZILIAN AGRARIAN REFORM PROCESS FROM 1985 TO 2001
}

\author{
Jeannette Antoinette van de Steeg ${ }^{1}$; Gerd Sparovek ${ }^{2 *}$; Simone Beatriz Lima Ranieri²; Rodrigo \\ Fernando Maule ${ }^{3}$; Miguel Cooper ${ }^{2}$; Durval Dourado Neto ${ }^{4}$; Marcelo Corrêa Alves ${ }^{5}$ \\ ${ }^{I}$ ILRI, P.O. Box 30709, 00100 Nairobi, Kenya \\ ${ }_{3}^{2}$ USP/ESALQ - Depto. de Solos e Nutrição de Plantas, C.P. 09 - 13418-900 - Piracicaba, SP - Brasil. \\ ${ }^{3}$ Entropix - R. Maria Manieiro 458, 13405-124 - Piracicaba, SP - Brasil. \\ ${ }^{4} U S P / E S A L Q$ - Depto. de Produção Vegetal. \\ ${ }^{5} U S P / E S A L Q-$ Siesalq. \\ *Corresponding author <gerd@esalq.usp.br>
}

\begin{abstract}
During the past 20 years, most settlements of the Brazilian Agrarian Reform (AR) have been established in or near better-preserved natural ecosystems, where environmental impact is likely to be negative and contribute to natural resources degradation. The objective of this work is providing a first, comprehensive insight of the impacts related to the environmental quality of these settlements, based on the primary survey of 4,340 AR settlements installed between 1985 and 2001. An index was calculated to integrate different aspects of environmental impacts in one single number. The index showed significant regional variation, with lower values (low environmental quality) for the North and Northeast of Brazil, intermediate values for the Central-west and Southeast, and high values for the South. Environmental impacts resulting from AR and settlement creation are slowly decreasing with time, but are still very high in absolute values. The lack of protection of riparian areas, cultivation of legal reserves, and deforestation, are the main concerns related to environmental impacts.
\end{abstract}

Key words: Brazil, deforestation, environmental index

\section{IMPACTOS AMBIENTAIS DA REFORMA AGRÁRIA NO BRASIL DE 1985 A 2001}

\begin{abstract}
RESUMO: Até o presente a maioria dos assentamentos da Reforma Agrária brasileira (AR) têm sido estabelecidos em ou perto de ambientes preservados, nos quais impactos ambientais negativos são esperados e podem levar à degradação dos recursos naturais. $\mathrm{O}$ objetivo deste trabalho foi apresentar uma visão ampla dos impactos relacionados à qualidade ambiental dos assentamentos com base em dados primários coletados em 4.340 projetos criados entre 1985 e 2001. Um índice foi criado com a finalidade de integrar diferentes aspectos ambientais. Este índice apresentou expressiva variação regional, com valores menores (baixa qualidade ambiental) nas regiões Norte e Nordeste do Brasil, intermediários na região CentroOeste e Sudeste, e elevados na região Sul. Os impactos ambientais resultantes da criação de assentamentos diminuíram com o tempo, mas ainda são elevados em termos absolutos. A falta de proteção de Áreas de Preservação Permanente, o cultivo de Reservas Legais e o desmatamento são os principais fatores relacionados aos impactos ambientais.

Palavras-chave: Brasil, desmatamento, índice ambiental
\end{abstract}

\section{INTRODUCTION}

Land ownership in Brazil is concentrated in a rather small percentage of the population. In the last census of agriculture (1996), the 49 thousand landowners with more than 1,000 hectares (about $1 \%$ of the producers) occupied $45 \%$ of the total farmed land (IBGE, 1996; Hoffmann, 1972). Limited access to land is a major rural poverty factor (Hall, 1990; Guanziroli et al., 2001). This scenario led to the establishment of a still-operative national Agrarian Reform (AR) program in the 1960's. Until 1985, AR was carried out in the context of colonization projects aimed at developing new agricultural regions. An analysis of the first 30 years of AR showed that 350,836 families were settled in 1,626 projects, most of them established in remote regions (Guedes Pinto, 1995). During the Fernando Henrique Cardoso's government (19952002), AR extended beyond colonization, aiming to enhance family farm units, which could result in a 
broad-based rural development with the economic benefits more equitably distributed (Guanziroli \& Cardim, 2000). After more than 40 years of AR, 500,000 families have been settled on 26 million ha (Guanziroli, 1999; Brasil, 1999), an area equivalent to UK.

The extensive colonization and abrupt change in land use caused by AR may influence the environment in different ways. Until recently, AR settlements were established in or near to preserved ecosystems. In these environments the antropic impact is likely to be negative. Deforestation for the establishment of agriculture is a good example of these impacts. A national inventory carried out in 2002 (Sparovek, 2003) shows that of the 26 million ha of land transformed under the AR in the period of 1985 to 2001, more than 7 million ha were deforested, equivalent to the area of Ireland.

This work is part of a wider research project designed to evaluate qualitative and quantitative aspects of Brazilian AR settlements created between 1985 and 2001 (Sparovek, 2003). This article presents the results related to the environmental quality of the settlements, with the goal of providing a comprehensive assessment of the environmental impacts in the areas affected by the Brazilian AR program.

\section{MATERIAL AND METHODS}

A countrywide survey on the AR settlements in Brazil was performed between July 2002 and September 2002 (Sparovek, 2003). The survey was performed in 4,340 settlements, all created between 1985 and 2001 with approximately 458,000 families. A team of government extension technicians, not familiar with the interviewees, applied three to five questionnaires in each settlement project. The interviews were made with representatives of the settlements associations, with a community leader and with the extension technician in charge of the settlement. Additional interviews were made in the case of settlements with more than one established association. A digital database was created out of the 14,414 questionnaires, and is available for download at http://www.nadd.prp.usp.br/ cis/index.aspx

Most queries had three possible levels of response. First, a quantitative response (65\% queries) represented by a numerical answer or a numerical equivalent (Example: the term "no" was considered equal to the value zero). Second a semi-quantitative response option, provided answers that were divided in five equal percentage classes. The third was a qualitative response, with the options "few", "half" or "majority". The structure of adopted answers allowed flexibility in the interviews and the possibil- ity to complete the questionnaire without inducing insecure or imprecise answers. For statistical purposes and calculations, semi-quantitative and qualitative answers were first mathematically converted to quantitative values. Also, during and after data processing, audit techniques were applied to exclude incomplete observations or incoherent answers. Less than $5 \%$ of data were excluded in any of the presented results.

Nine of 89 queries in the survey referred to the state of conservation of the "Áreas de Proteção Permanente - APP" (Legally Protected Areas - LPA) and the "Reservas Legais - RL" (Legal Reserves LR); none query authorized extraction of forest products or mining, degradation of the soil by erosion, deforestation after the creation of the settlement, and reforestation or actions to improve environmental quality. Queries on hunting or capturing of wild animals were also applied, even though these are prohibited activities all through Brazil. LPA comprise riparian strips near rivers and other water bodies, protected by Brazilian federal laws and should be kept with natural vegetation. LR is the portion of any farmland that cannot be used for agricultural production and can never be legally deforested. This portion of a rural property or settlement may vary from $80 \%$ in the Amazon region to $20 \%$ in the more developed South and Southeast of Brazil. The translated queries are presented in the Appendix.

Answers to the questionnaires were combined in a single index. This index was created to integrate different aspects of environmental impacts in one number, allowing a more comprehensive comparison of all settlements within a national framework. The index varies from 0 to $100 ; 0$ being the minimum mathematical value that also characterizes the worst situation (i.e., greatest environmental degradation), and 100 the maximum value that characterizes the best-possible situation (i.e., least environmental damage). More detailed explanation of the analytical and survey procedures and index calculation can be seen in Sparovek (2003). The index was calculated by combining mathematically the following parameters: a) percentage of LPA within undisturbed or near to undisturbed condition (Query 81); b) percentage of LR within undisturbed or near to undisturbed condition (Query 82); c) percentage of families that extract forest products without legal authorization (Query $83)$; d) percentage of settlement area impacted by erosion in relation to the number of families living in the settlement (Queries 21 and 85); e) percentage of the LPA and LR in settlement areas where activities aimed towards environmental recovery have been undertaken (Queries 3 and 88). 
The index of environmental quality (EQ) was calculated as follows:

$$
E Q=\left[1-\left\{\frac{\sum_{i=1}^{4} E Q_{i} E_{i}}{\sum_{i=1}^{4} E_{i}}\right\}\right] \times 100
$$

in which $\mathrm{E}_{1}, \mathrm{E}_{2}, \mathrm{E}_{3}$ and $\mathrm{E}_{4}$ refer to the weights referent to the auxiliary variables $\mathrm{EQ}_{1}, \mathrm{EQ}_{2}, \mathrm{EQ}_{3}$ and $\mathrm{EQ}_{4}$. The auxiliary variables deplete the EQ value. Grater values of the auxiliary variables indicate greater depletion (i.e., more environmental problems) resulting in a lower final EQ value.

$$
\begin{aligned}
& E Q_{1}=1-\frac{\frac{\sum_{i=1}^{n_{3}} Q 81_{i}}{n_{81}}}{100} \\
& E Q_{2}=1-\frac{\frac{\sum_{i=1}^{n_{4}} Q 82_{i}}{n_{82}}}{100} \\
& E Q_{3}=1-\frac{\frac{\sum_{i=1}^{n_{5}} Q 83_{i}}{n_{83}}}{\sum_{i=1}^{n_{1}} Q 3_{i}} \\
& E Q_{4}=\frac{\sum_{i=1}^{n_{3}} Q 85_{i}}{\sum_{85}^{n_{2}} Q 21_{i}} \\
& n_{21}^{n_{6}}
\end{aligned}
$$

in which Q3 $3_{\mathrm{i}}$ Q21, Q81, Q82 ${ }_{\mathrm{i}}, \mathrm{Q} 83_{\mathrm{i}}$, and $\mathrm{Q} 85_{\mathrm{i},}$ and $\mathrm{n}_{3}$, $\mathrm{n}_{21}, \mathrm{n}_{81}, \mathrm{n}_{82}, \mathrm{n}_{83}$, and $\mathrm{n}_{85}$, refer to the variables and number of valid answers corresponding to the queries 3, 21, $81,82,83$, and 85 of the questionnaire (Appendix) respectively. The auxiliary variables were weighted for index calculation. The weights reflect the expert opinion from the research group, discussed with the government staff responsible for environmental issues of the
AR program. The objective of the weights is pointing out the most important environmental issues based on the current state-of-the-art opinion. The weights referring to the auxiliary variables were determined as i) the weight of the percentage of conservation of LPA (E1) $=1.00$; ii) the weight of the percentage of conservation of LR $(E 2)=1.00$; iii) the weight of the illegal extraction of forest products $(\mathrm{E} 3)=0.60$; and the weight of the degradation by erosion $(\mathrm{E} 4)=0.60$.

For calculations purposes, period 1985-1994 was combined in one set and period 1995-2001 in another. This division into two time periods makes it possible to compare the two time periods and minimizes the tendency of short-term political events in the first period.

\section{RESULTS AND DISCUSSION}

The survey covered most settlements of the agrarian reform created in Brazil from 1985 to 2001, allowing comparison of responses and the derived index within a national framework. The spatial distribution of the environment quality index (EQ) is represented in Figure 1. Table 1 shows the average, maximum and minimum values of overall environment quality index for Brazil and its regions, the total number of settlements and the area covered by these settlements per region. The EQ index, which integrates aspects of environmental impacts, shows significant regional variation, with lower values for the North and Northeast of Brazil, intermediate values for the Central-west and Southeast, and high values for the South. For the period 1985-1994, the South presented the highest environmental quality index, followed by the Southeast. The regions Central West, North and Northeast had the lowest indexes. The higher values (better preserved) occurred in the more recent period, 1995 to 2001. For this period the South presented the highest index, followed by Central-west, Southeast, and North and Northeast. In general the environmental quality index in the South indicates better environmental quality than in the North and Northeast. The South and Southeast, and in lesser extend the Central West, are the traditional agricultural regions of Brazil. In these regions, most settlements are created on unproductive farms. In the North and Northeast, settlements are still been created as part of a colonization process to develop new agricultural frontiers.

Better understanding of the composition of the environment quality index is possible by looking at the outcome of the individual variables that contribute to the index value. Tables 2 and 3 show the depletion factor of the individual auxiliary variables of EQ for the period of 1985-1994 and 1995-2001, respectively. 


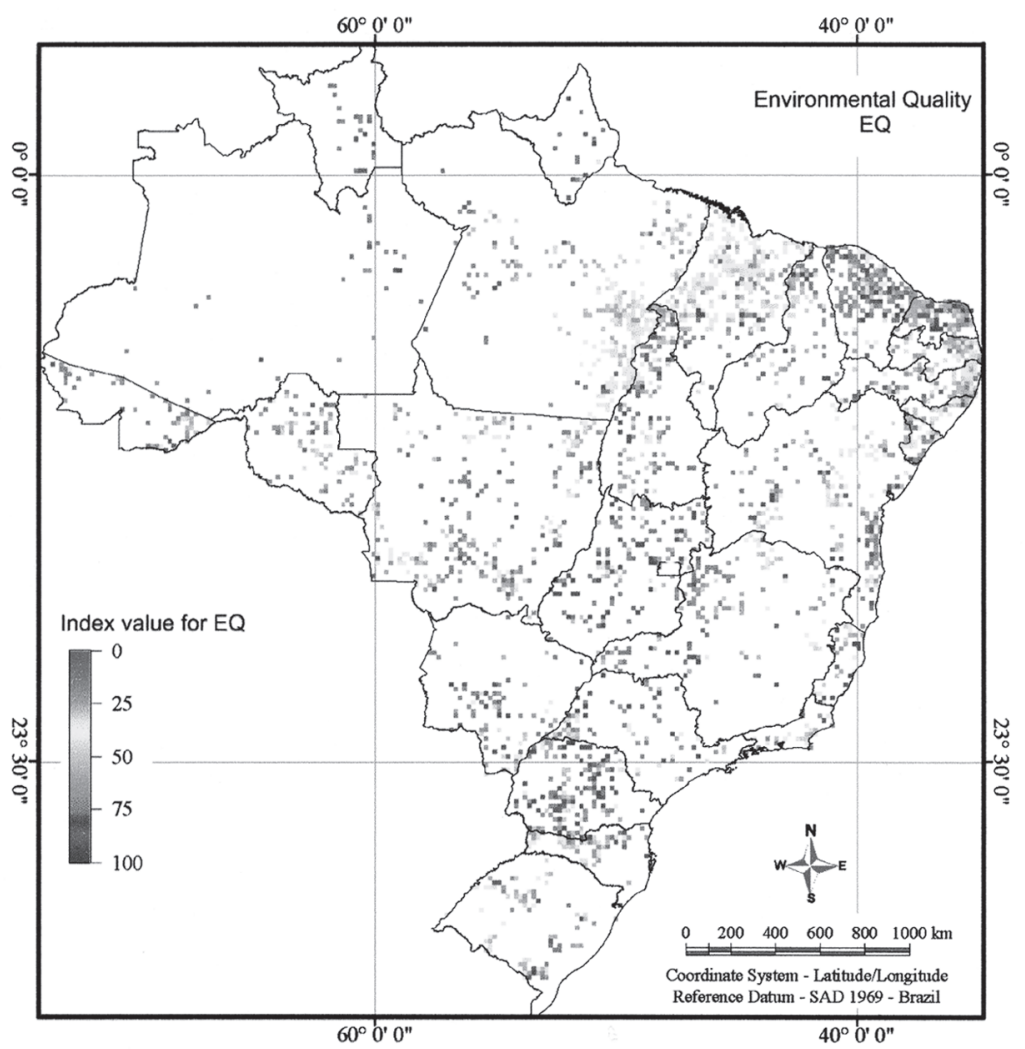

Figure 1 - Values of the Environmental Quality index (EQ) of the agrarian reform settlements in Brazil. Every dot represents the location of a settlement and the colors the value of EQ.

Table 1 - Values of the environmental quality index for Brazil and per region, and the total surface area and number of the settlements.

\begin{tabular}{|c|c|c|c|c|c|c|c|c|}
\hline & \multirow{3}{*}{$\begin{array}{c}\text { Total area } \\
\text { of settlements (ha) }\end{array}$} & \multirow{3}{*}{$\begin{array}{c}\text { Nr. of } \\
\text { settlements }\end{array}$} & \multicolumn{6}{|c|}{ Environmental Quality Index } \\
\hline & & & \multicolumn{3}{|c|}{$(1985-1994)$} & \multicolumn{3}{|c|}{$(1995-2001)$} \\
\hline & & & Average & Maximum & Minimum & Average & Maximum & Minimum \\
\hline North & $5,446,283$ & 1,916 & 61 & 70 & 52 & 63 & 72 & 55 \\
\hline Northeast & $13,484,124$ & 902 & 60 & 67 & 52 & 63 & 71 & 53 \\
\hline Central-West & $6,029,828$ & 588 & 62 & 73 & 52 & 73 & 82 & 63 \\
\hline South-East & 537,863 & 520 & 68 & 79 & 59 & 71 & 82 & 61 \\
\hline South & $1,049,494$ & 371 & 73 & 82 & 63 & 75 & 84 & 63 \\
\hline Brazil & $26,547,592$ & 4,297 & 64 & 72 & 55 & 66 & 75 & 57 \\
\hline
\end{tabular}

The mean value for LPA in Table 3 is 0.53 , that is, $53 \%$ of the LPA in the period of 1995-2001 was declared to be without natural vegetation. LPA are riparian areas that should be covered by natural vegetation, usually forests, to protect the rivers, wild life and preserve biodiversity (Matson et al., 1997; Nilsson et al., 1997; Sala et al., 2000). The LPA factor evaluates the percentage of this area that is not covered by forest (i.e., used for agriculture or inherited degradation of previous agricultural land use). In both periods (1995-2001 and 1985-1994) the highest percentages of preserved LPA were found in the South, although it should be emphasized that only $63 \%$ and $54 \%$ was covered by forest, respectively. Thus, a great extend of LPA are without coverage of natural or recovered natural vegetation. This may be because already before AR, South and Southeast Brazil suffered intense and continuous process of removal of the natural forest in the colonization period of the XIX Century (Rodrigues \& Leitão, 2000). As a result, only a few and mostly small fragments of natural forests remain on LPA. In both periods (1995-2001 and 1985-1994) the lowest percentages of preserved LPA were found in the North and Northeast regions (highest depletion 
Table 2 - Environmental quality index (EQ) and the depletion ${ }^{1}$ by the individual auxiliary variables for Brazil, regions, and states during the period of 1985-1994.

\begin{tabular}{|c|c|c|c|c|c|}
\hline Brazilian Federal States & EQ & $\mathrm{LPA}^{2}$ & $\mathrm{LR}^{3}$ & Illegal extraction of forest products & Erosion \\
\hline Acre & 77 & 0.39 & 0.32 & 0.03 & 0.02 \\
\hline Alagoas & 52 & 0.80 & 0.55 & 0.10 & 0.09 \\
\hline Amapá & 76 & 0.41 & 0.26 & 0.19 & 0.01 \\
\hline Amazonas & 85 & 0.22 & 0.20 & 0.16 & 0.06 \\
\hline Bahia & 64 & 0.62 & 0.48 & 0.03 & 0.05 \\
\hline Ceará & 74 & 0.44 & 0.33 & 0.02 & 0.06 \\
\hline Espírito Santo & 75 & 0.43 & 0.33 & 0.01 & 0.04 \\
\hline Goiás & 68 & 0.44 & 0.49 & 0.02 & 0.05 \\
\hline Maranhão & 46 & 0.80 & 0.79 & 0.07 & 0.03 \\
\hline Mato Grosso & 56 & 0.61 & 0.69 & 0.04 & 0.05 \\
\hline Mato Grosso do Sul & 67 & 0.43 & 0.54 & 0.03 & 0.10 \\
\hline Minas Gerais & 68 & 0.45 & 0.43 & 0.04 & 0.13 \\
\hline Pará & 44 & 0.76 & 0.91 & 0.07 & 0.04 \\
\hline Paraíba & 51 & 0.74 & 0.69 & 0.02 & 0.11 \\
\hline Paraná & 88 & 0.24 & 0.17 & 0.06 & 0.12 \\
\hline Pernambuco & 48 & 0.77 & 0.72 & 0.13 & 0.02 \\
\hline Piauí & 66 & 0.55 & 0.49 & 0.02 & 0.05 \\
\hline Rio de Janeiro & 52 & 0.72 & 0.71 & 0.00 & 0.11 \\
\hline Rio Grande do Norte & 72 & 0.69 & 0.13 & 0.05 & 0.05 \\
\hline Rio Grande do Sul & 58 & 0.65 & 0.80 & 0.01 & 0.07 \\
\hline Rondônia & 66 & 0.56 & 0.65 & 0.03 & 0.01 \\
\hline Roraima & 90 & 0.23 & 0.06 & 0.05 & 0.04 \\
\hline Santa Catarina & 59 & 0.68 & 0.70 & 0.02 & 0.11 \\
\hline São Paulo & 79 & 0.29 & 0.33 & 0.05 & 0.06 \\
\hline Sergipe & 63 & 0.64 & 0.47 & 0.02 & 0.01 \\
\hline Tocantins & 63 & 0.58 & 0.53 & 0.02 & 0.02 \\
\hline \multicolumn{6}{|l|}{ Brazilian Regions } \\
\hline North & 61 & 0.58 & 0.62 & 0.06 & 0.03 \\
\hline Northeast & 60 & 0.65 & 0.52 & 0.05 & 0.05 \\
\hline Central-west & 62 & 0.52 & 0.60 & 0.03 & 0.07 \\
\hline Southeast & 68 & 0.48 & 0.46 & 0.03 & 0.09 \\
\hline South & 73 & 0.46 & 0.45 & 0.04 & 0.11 \\
\hline \multicolumn{6}{|l|}{ Mean Value } \\
\hline Brazil & 64 & 0.57 & 0.54 & 0.05 & 0.06 \\
\hline
\end{tabular}

${ }^{1}$ The depletion varies from 0 to 1 . Zero indicates no depletion of EQ by the individual variable (e.g.: LPA $=0$ corresponds to $100 \%$ of the LPA in preserved conditions) and 1 indicates maximum depletion (e.g.: Illegal extraction of forest products $=1.0$ corresponds to $100 \%$ of the families with illegal extraction activity). ${ }^{2} \mathrm{LPA}=$ Legally Protected Area. ${ }^{3} \mathrm{LR}=$ Legal Reserve.

values of LPA). This can be explained by the fact that $\mathrm{AR}$ is performed on new agricultural regions, thus needing deforestation to create new agricultural land. The regional variation of LPA depletion factor is large, varying for the different states of Brazil between 0.23 and 0.80 for the period 1985-1994, and between 0.18 and 0.73 for the period 1995-2001. The large variation within regions does not allow general statements concerning LPA, but along time, LPA are more effectively preserved. The values for LPA depletion are lower for the period 1995-2001 than for the period 1985-1994.
LR is the portion of any farmland that cannot be used for agricultural production and is legally not allowed to be deforested. The LR depletion factor evaluates the proportion of the settlement not covered by forest. When evaluated in percentage, these values indicate that currently (Table 3 ) about $52 \%$ of LR areas are being preserved, covered either by natural or recovered natural vegetation (without agricultural use). In the period of 1985-1994, the South and Southeast had the lowest depletion values for this factor $(0.45$ and 0.46 , respectively). In the following period, regions Southeast and Central-West had the lowest depletion 
Table 3 - Environmental quality index (EQ) and the depletion ${ }^{1}$ by the individual auxiliary variables for Brazil, regions, and states during the period of 1995-2001.

\begin{tabular}{|c|c|c|c|c|c|}
\hline Brazilian Federal States & EQ & $\mathrm{LPA}^{2}$ & $\mathrm{LR}^{3}$ & Illegal extraction of forest products & Erosion \\
\hline Acre & 74 & 0.43 & 0.36 & 0.04 & 0.01 \\
\hline Alagoas & 59 & 0.68 & 0.51 & 0.05 & 0.05 \\
\hline Amapá & 83 & 0.27 & 0.24 & 0.10 & 0.03 \\
\hline Amazonas & 92 & 0.18 & 0.11 & 0.09 & 0.04 \\
\hline Bahia & 68 & 0.57 & 0.39 & 0.02 & 0.04 \\
\hline Ceará & 78 & 0.38 & 0.26 & 0.04 & 0.06 \\
\hline Espírito Santo & 77 & 0.39 & 0.30 & 0.00 & 0.03 \\
\hline Goiás & 79 & 0.30 & 0.33 & 0.03 & 0.04 \\
\hline Maranhão & 49 & 0.73 & 0.77 & 0.06 & 0.04 \\
\hline Mato Grosso & 68 & 0.46 & 0.50 & 0.05 & 0.04 \\
\hline Mato Grosso do Sul & 78 & 0.31 & 0.34 & 0.03 & 0.08 \\
\hline Minas Gerais & 74 & 0.41 & 0.33 & 0.06 & 0.07 \\
\hline Pará & 50 & 0.68 & 0.83 & 0.07 & 0.03 \\
\hline Paraíba & 55 & 0.72 & 0.59 & 0.04 & 0.10 \\
\hline Paraná & 85 & 0.26 & 0.22 & 0.07 & 0.07 \\
\hline Pernambuco & 59 & 0.66 & 0.58 & 0.03 & 0.04 \\
\hline Piauí & 69 & 0.60 & 0.32 & 0.06 & 0.04 \\
\hline Rio de Janeiro & 61 & 0.59 & 0.57 & 0.03 & 0.10 \\
\hline Rio Grande do Norte & 74 & 0.61 & 0.11 & 0.08 & 0.04 \\
\hline Rio Grande do Sul & 63 & 0.47 & 0.72 & 0.01 & 0.06 \\
\hline Rondônia & 76 & 0.42 & 0.38 & 0.14 & 0.01 \\
\hline Roraima & 87 & 0.27 & 0.10 & 0.06 & 0.01 \\
\hline Santa Catarina & 68 & 0.52 & 0.55 & 0.09 & 0.05 \\
\hline São Paulo & 68 & 0.47 & 0.47 & 0.02 & 0.06 \\
\hline Sergipe & 61 & 0.68 & 0.49 & 0.03 & 0.01 \\
\hline Tocantins & 72 & 0.44 & 0.39 & 0.04 & 0.01 \\
\hline \multicolumn{6}{|l|}{ Brazilian Regions } \\
\hline North & 63 & 0.53 & 0.58 & 0.07 & 0.02 \\
\hline Northeast & 63 & 0.62 & 0.48 & 0.05 & 0.05 \\
\hline Central-west & 73 & 0.38 & 0.42 & 0.04 & 0.04 \\
\hline Southeast & 71 & 0.44 & 0.40 & 0.04 & 0.06 \\
\hline South & 75 & 0.37 & 0.44 & 0.05 & 0.06 \\
\hline \multicolumn{6}{|l|}{ Mean Value } \\
\hline Brazil & 66 & 0.53 & 0.48 & 0.05 & 0.04 \\
\hline
\end{tabular}

${ }^{1}$ The depletion varies from 0 to 1 . Zero indicates no depletion of EQ by the individual variable (e.g.: LPA $=0$ corresponds to $100 \%$ of the LPA in preserved conditions) and 1 indicates maximum depletion (e.g.: Illegal extraction of forest products $=1.0$ corresponds to $100 \%$ of the families with illegal extraction activity). ${ }^{2} \mathrm{LPA}=$ Legally Protected Area. ${ }^{3} \mathrm{LR}=$ Legal Reserve.

values, 0.40 and 0.42 , respectively. Also this factor shows a large variation within regions. In the period of 1985-1994, the variation between the states in the South region was 0.17 to 0.80 . The large variation does not allow general statements concerning this factor. When considering specific states, the lowest preservation occurred in Maranhão, Pará and Rio Grande de Sul. The LR was less depleting than LPA, but still influential. The LR depleting value showed a slight improvement with time passing from a value of 0.54 during 1985-1994, to 0.48 during 1995-2001. A possible reason of these lower values in the more recent
AR projects, while taken into account that still most settlements are created in the North and Northeast, is that new settlements are still initiating their agricultural exploration. In such a situation, there is often no need or a lack of conditions to explore more land, resulting in less pressure to explore the LR area.

The factor illegal extraction of forest products presented low depletion values for all regions. The North region showed largest percentage of families dedicated to commercial extraction of wood or other forest products without environmental license (7\%). In this region, the states of Amapá, Amazonas and 
Rondônia were the ones that presented the largest illegal extraction activities. But also the state of Santa Catarina, in the South, registered a relatively high value for this factor $(9 \%)$, equaling the state of Amazonas. For this factor it should be acknowledged that not all interviewees may have reported illegal activities, and an underestimation may have happened.

The erosion depletion factor refers to those areas where erosion problems prevent normal agricultural production. The registered values were low for all regions. The South and Southeast had higher values. These results are probably caused by a more intense use of agricultural machinery and tillage, typical of these regions. Another aspect that can have contributed to a higher degradation is the fact that in these regions the AR areas have been more frequently cultivated previously, and thus degraded before implantation of the settlements. The areas with severe soil degradation are, many times, left idle (unproductive) making them legally eligible for AR (expropriation). Although the values of the erosion component have been relatively low, it should be considered that the question refers to erosion that causes direct problems to agricultural production. In the farmers perspective, this will be associated to difficult agricultural machinery traffic and loss of seeds and plants through dragging. Other forms of erosion, such as inter-rill and rill erosion, were not included in the formulation of the queries. These types of erosion can occur in a less perceptible way, but may contribute significantly to environmental degradation and impact production in the long run (Sparovek \& De Maria, 2003).

Environmental recovery by ecosystem rehabilitation and reforestation (planted forests, recovery of riparian vegetation or natural vegetation, and adoption of agroforestry systems) have been carried out in 871 thousand hectares according to the declarations of the interviewees. This number is small when compared to the total area of the settlements (26.5 million hectares), or the total deforested area, illegal or legally, after the creation of the projects (7.2 million hectares). A possible explanation for this is the absence of resources, i.e. the financing of created AR settlements are available mainly for the establishment of agricultural production, commercialization and implantation of basic infrastructure, and not for environmental issues.

\section{CONCLUSIONS}

AR is currently carried out to promote and support family agriculture, which can result in more sustainable agriculture and development of social structures. This attempt to improve the standard of living of the rural poor and landless farmers is often associ- ated with environmental degradation as the settlements as established in or near better-preserved environments. The environmental impacts resulting from AR and settlements are slowly decreasing with time, but are still very high in absolute values. The lack of protection of riparian areas, cultivation of legal reserves, and deforestation, are the main issues related to environmental impacts.

\section{ACKNOWLEDGEMENTS}

This work was made possible by the joint efforts of the National Institute for Colonization and Agrarian Reform (INCRA), the University of São Paulo (USP), and National Institute for Geography and Statistics (IBGE), with the support of FAO (Food and Agriculture Organization of the United Nations).

\section{Appendix: Queries of the questionnaire related to environmental impacts}

$\mathrm{Q}_{3}$ ) Total area of the settlement project (ha) according to the Regulation of Creation, considering all the rectification.

$\mathrm{Q}_{21}$ ) Current number of families living in the settlement project in individual houses.

$\mathrm{Q}_{81}$ ) Percentage of Legally Protected Areas (LPA represented by riparian areas, river margins and very steep areas) that are preserved (without agricultural use) and that has natural or recovered forest coverage (e.g. riparian forest).

$\mathrm{Q}_{82}$ ) Percentage of the area of Legal Reserve (LR) that was preserved (without agricultural use) and that has natural or recovered forest coverage.

$\mathrm{Q}_{83}$ ) Families dedicated to the commercial extraction of wood and other forest resources (e.g. coal) that require environmental license but that is not legalized.

$\mathrm{Q}_{85}$ ) Percentage of the area degraded by soil erosion and thus not suitable for agricultural production.

$\mathrm{Q}_{88}$ ) Area of the settlement project with improvement of forest resources by recuperation riparian forests, reforestation or adoption of agro-forest systems.

\section{REFERENCES}

BRASIL. Ministério do Desenvolvimento Agrário. Balanço da reforma agrária e da agricultura familiar. Brasília: MDA; INCRA, 1999. $51 \mathrm{p}$.

GUANZIROLLI, C.E. The agrarian reform and the globalization of the economy. Brazil's case. Brasília: MDA/FAO, 1999. (Report, 5). GUANZIROLI, C.E.; CARDIM, S.E. Novo retrato da agricultura familiar: o Brasil redescoberto. Brasília: INCRA/FAO, 2000. 74p. GUANZIROLI, C.E.; ROMEIRO, A.; BUAINAIN, A.M.; SABBATO, A.D.; BITTENCOURT, G. Agricultura familiar e reforma agrária no século XXI. Rio de Janeiro: Garamond Editora, 2001.

GUEDES PINTO, L.C. Reflexões sobre a política agrária brasileira no período de 1964-1994. Brasília: ABRA, 1995. (Boletim da Associação Brasileira de Reforma Agrária, 1). 
HALL, A. Land tenure and land reform in Brazil. In: PROSTERMAN, R.L.; TEMPLE, M.; HANDSTAD, T. (Ed.). Agrarian reform and grassroots development: Ten case studies. Boulder: L. RIENNER, 1990.

HOFFMANN, R. Distribuição da renda e da posse da terra no Brasil. Reforma Agrária, v.2, p.2-12, 1972.

INSTITUTO BRASILEIRO DE GEOGRAFIA E ESTATÍSTICA IBGE. Base de informações municipais: Censo agropecuário 19951996. 2.ed. Rio de Janeiro: IBGE, 1996. 1 CD-ROM.

MATSON, P.A.; PARTON, W.J.; POWER, A.G.; SWIFT, M.J. Agricultural intensification and ecosystem properties. Science, v.277, p. 504-509, 1997.

NILSSON, C.; JANSSON, R.; ZINKO, U. Long term responses of river margin vegetation to water level regulation. Science, v.276, p.798$800,1997$.

RODRIGUES, R.R.; LEITÃO, H.F. Matas ciliares: Conservação e recuperação. São Paulo: EDUSP; FAPESP, 2000. 320p.
SALA, O.E.; CHAPIN III, F.S.; ARMESTO, J.J.; BERLOW, E.; BLOOMFIELD, J.; DIRZO, R.; HUBER-SANWALD, E.; HUENNEKE, L.F.; JACKSON, R.B.; KINZIG, A.; LEEMANS, R.; LODGE, D.M.; MOONEY, H.A.; OESTERHELD, M.; POFF, N.L.; SYKES, M.T.; WALKER, B.H.; WALKER, M.; WALL, D.H. Global biodiversity scenarios for the year 2100 . Science, v.287, p.1770-1774, 2000.

SPAROVEK, G. (Ed.). A qualidade dos assentamentos da reforma agrária brasileira. São Paulo: Páginas e Letras, 2003. 204p.

SPAROVEK, G.; DE MARIA, I.C. Multiperspective analysis of erosion tolerance. Scientia Agricola, v.60, p.409-416, 2003.

Received April 18, 2005

Accepted March 07, 2006 